\title{
Exergy and Energy Analysis of a Tubular Solar Still with and without Fins: Comparative Theoretical and Experimental Approach
}

Prof. Dr. Ravishankar Sathyamurthy ( $\sim$ raviannauniv23@gmail.com )

KPR Institute of Engineering and Technology https://orcid.org/0000-0002-2881-3455

Abd Elnaby Kabeel

Tanta University

Ali Chamkha

Kuwait College of Science and Technology

Hemanth Arun Kumar

BS Abdur Rahman Crescent Engineering College: B S Abdur Rahman Crescent Institute of Science \&

Technology

Hariprasath Venkateswaran

BS Abdur Rahman Crescent Engineering College: B S Abdur Rahman Crescent Institute of Science \& Technology

Athikesavan Muthu Manokar

BS Abdur Rahman Crescent Engineering College: B S Abdur Rahman Crescent Institute of Science \& Technology

Ramani Bharathwaaj

KPR Institute of Engineering and Technology

Sathiyaseelan Vasanthaseelan

KPR Institute of Engineering and Technology

\section{Research Article}

Keywords: Tubular solar still, fins, desalination

Posted Date: June 14th, 2021

DOI: https://doi.org/10.21203/rs.3.rs-326378/v1

License: (a) (i) This work is licensed under a Creative Commons Attribution 4.0 International License.

Read Full License 
Version of Record: A version of this preprint was published at Environmental Science and Pollution Research on August 28th, 2021. See the published version at https://doi.org/10.1007/s11356-021-16065w. 


\section{Exergy and energy analysis of a tubular solar still with and without fins: Comparative}

theoretical and experimental approach

Ravishankar Sathyamurthy ${ }^{\mathrm{a}}$, Abd Elnaby Kabeel ${ }^{\mathrm{b}, \mathrm{c}}$, Ali Chamkha ${ }^{\mathrm{d}, \mathrm{e} *}$, Hemanth Arun Kumar ${ }^{\mathrm{f}}$, Hariprasath Venkateswaran ${ }^{\mathrm{f}}$, Athikesavan Muthu Manokar ${ }^{\mathrm{f}}$, Ramani Bharathwaaj ${ }^{\mathrm{a}}$, Sathiyaseelan Vasanthaseelan ${ }^{\mathrm{a}}$

a Department of Mechanical Engineering, KPR Institute of Engineering and Technology, Arasur, Coimbatore, Tamil Nadu, India (raviannauniv23@gmail.com)

${ }^{b}$ Mechanical Power Engineering Department, Faculty of Engineering, Tanta University, Egypt (kabeel6@ hotmail.com)

${ }^{c}$ Faculty of Engineering, Delta University for Science and Technology, Gamasa, Egypt

${ }^{\mathrm{d}}$ Faculty of Engineering, Kuwait College of Science and Technology, Doha District, Kuwait (a.chamkha@kcst.edu.kw)

${ }^{\mathrm{e}}$ Center of Excellence in Desalination Technology, King Abdulaziz University, PO Box 80200, Jeddah 21589, Saudi Arabia

${ }^{\mathrm{d}}$ Department of Mechanical Engineering, B.S.Abdur Rahman Crescent Institute of Science and Technology, Chennai - 600 048, India (ahemanthkumar27@gmail.com, hariprasat16@gmail.com) *Corresponding author

Dr. Ali J Chamkha, Institute of Research and Development, Duy Tan University, Da Nang 550000, Vietnam. achamkha@yahoo.com

\section{Abstract}

Today, availability of clean water is hard as the residents are expanding and moving fast to achieve rapid urbanization as a result need for clean water has been raised. Solar stills are the solution to desalinate to obtain pure water. This paper represents the theoretical and experimental study of tubular solar still with and without fins. The reading was recorded from 8:00 AM to 6:00 PM. Efficiency of TSS with fins and without fins are $23.39 \%$ and $13.76 \%$ respectively. The rate of irreversibility from the basin of TSS with flat is higher than TSS with finned absorber. Similarly, the rate of irreversibility from water is significantly reduced using finned absorber. Also, the exergy efficiency of TSS with finned absorber is higher compared to TSS with flat absorber.

Keywords: Tubular solar still; fins; desalination

\section{Introduction}

Nearly about 780 Million of people lack access to water around the world. It is predicted that $50 \%$ of the world population will suffer from water scarcity in 2050 . To fulfill the necessity 
of desalination of water can be done. Solar stills can be used to remove salt from the sea water, solar still desalination is free from pollution and provides high quality pure form of water. The setup of this solar still desalination can be used in residential areas to overcome water scarcity in the urban areas. The drawback of solar stills is the low productivity rate and require constant sunlight for the process to be done effectively (Abdelgaied et al. (2020); Muthu Manokar et ak, (2020); Balachandran et al. (2020); Attia et al. (2020, 2021); Muthu Manokar et al. (2020); Kumar et al. (2020); Sharshir et al. (2020); Essa et al. (2020); Fath et al. (2003)). For a single slope and pyramid shaped Fath et al. (2003) carried out a thermo economic analysis. Their study revealed that, the performance of traditional solar still was significantly higher than the solar still in the shape of a pyramid. There is an increase of about $30 \%$ in the fresh water produced using conventional solar still than pyramid shaped solar still. Abu-Arabi and Zurigat (2005) performed a simulation on double glass cover cooling with regenerative effect and conventional solar still. Their results revealed that the regenerative effect from double glass cover cooling improved the cumulative yield by $70 \%$ than a single slope conventional solar still. Arunkumar et al. (2013) used a concentric tubular solar still and in addition to that a parabolic concentrator is attached to focus the incoming solar radiation. Additionally, air- and water-cooling methods were employed to reduce the cover temperature. Through improved cooling of air and water flow the productivity of water produced was increased from 2050 $\mathrm{ml} / \mathrm{day}$ to $3050 \mathrm{ml} / \mathrm{day}$. With continuous cooling water flow in the concentric tube, the fresh water produced was furthermore increased to $5000 \mathrm{ml} / \mathrm{day}$. Arunkumar et al (2016) enhanced the productivity of compound parabolic concentrator tubular solar stills. A saline water trough of rectangular shape was designed and fabricated and this trough is attached along with the pyramid type and single slope solar still. The integrated solar still has produced an accumulated yield of $7770 \mathrm{ml} /$ day whereas, the single slope solar still produced a maximum cumulative yield of $6460 \mathrm{ml} / \mathrm{day}$. Kabeel et al (2019) improved the performance of the tubular solar still by controlling the cover cooling and water depth. It is found that lowering the water depth increases the performance, by this the productivity of fresh water rate reached a maximum value of $5.85 \mathrm{~L} / \mathrm{m}^{2}$. Elashmawy (2019) describes the performance of the high temperature stand-alone tubular solar still by changing the thickness and surface cooling. By reducing the thickness by $40 \%$ the productivity and efficiency had been enhanced by $21 \%$ and $13.35 \%$ respectively. Elashmawy (2017) conducted three experiments using tubular solar still namely rectangular trough with a black cloth, half cylindrical trough without cloth and parabolic concentrator-solar tracking system integrated half cylindrical trough without cloth. The daily yield is about $4.71,3.6$ and $3.53 \mathrm{~L} / \mathrm{m}^{2}$ day. Panchal (2015) have proved that the combined 
application of both black granite gravel and vacuum tubes increased the DBSS fresh water productivity to $65 \%$ and with the application of vacuum tubes alone in DBSS enhanced the fresh water productivity by $56 \%$. Panchal and Thakkar (2016) had validated the thermal and experimental analysis carried out on solar still directly coupled with evacuated tubes during summer and winter climatic conditions. They concluded that the introduction of evacuated tubes and Polyurethane Foam type insulation material to the experimental model enhanced the distillate output and also helps in reducing heat loss. Rahbar et al. (2015) proposed new correlations to predict the fresh water produced and heat transfer coefficient of an TSS using CFD and theoretical approach. From the characteristic curve of their study, it can be concluded that on lower cover temperature and higher water temperature, the yield from TSS was higher. Sarhaddi et al. (2017) carried out experiments on a weir cascade solar still by incorporating PCM energy storage to estimate the energy and exergy under clear sky condition and semicloudy condition. From the results of exergy and energy analysis, it has been summarized that the still with PCM is preferred for semi-cloudy days and still without PCM is suitable for sunny days. Experiments conducted on a typical sunny day with clear sky revealed that the exergy efficiency of solar still without PCM was slightly lower than semi-cloudy days, whereas, the energy efficiency reduced using PCM during semi-cloudy condition as it affects the melting process of PCM beneath the basin. Shanmugam et al. (2018) conducted experiments to study the yield enhancement of solar still by incorporating nanoparticles and PCM in the basin of the still model. The distillate yield of SB-SS with wick material by nanoparticles as FWCW and PCM is 4.120 and $7.460 \mathrm{~kg} / \mathrm{m}^{2}$ day. Sharshir et al. (2016) studied the performance of continuous solar desalination model comprised of HDH unit and SS with an evacuated solar water heater unit. The experimental study shows that the distillate productivity of the SS with exit warm water from HDH is $242 \%$ higher than the CSS system and there is about $39 \%$ rise in the gain output ratio. The effect on forced convection on cover cooling of pyramid solar still was experimentally carried out by Taamneh \& Taamneh (2012). A small DC powered fan was used to cool the entire cover surface. Experimental results revealed that an improvement in daily freshwater yield of about 2.99 litres per day (25\%) is achieved using with forced convection which is higher compared to the free convection still. Bhaskar and Rai (2018) investigated the productivity and exergy analysis of tubular solar still operated in active and passive mode individually. This study showed that the daily fresh water yield of the TSS in active mode is $52 \%$ more than the passive mode and also the TSS with fan had exergy efficiency of about $133 \%$ higher than the TSS in passive mode. Xie et al. (2016) have designed and constructed a novel conceptual design of low temperature- multi effect desalination system 
that comprises an array of Tubular Solar Still capable of producing freshwater independently to investigate the performance affecting parameters- vacuum pressures, heating conditions and evaporation temperatures. Panchal and Mohan (2017) presented a cost effective optimized solar still model with its different approaches of augmenting the productivity of solar still by adding some modification such as fins, increasing the number of effects and adding energy absorbing materials inside the basin.

The effect of humid air present in the tubular enclosure on heat and mass transfer was experimentally studied by Ahsan and Fukuhara (2010). Other similar configuration of solar still includes improving the exposure area by attaching hollow and solid fins. In addition to the fins, additional materials such as wick material, PCM, ethanol, solar pond, etc. can further increase the fresh water. The proposed model provided new outputs for the tubular solar still. Finally, it is concluded that the daily and hourly production of the Tubular solar still can be accurately predicted.

\section{Experimental setup and procedure}

Tubular solar still with Fins

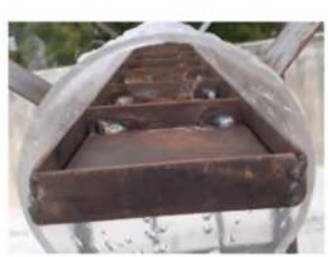

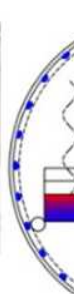

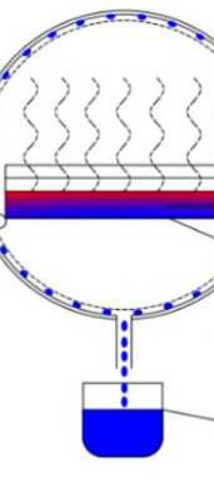

Tubular solar still (TSS)

$$
\text { Tubular cover }
$$

Water droplet condensed

Evaporated water (Vapor) -

Water placed in trough Trough

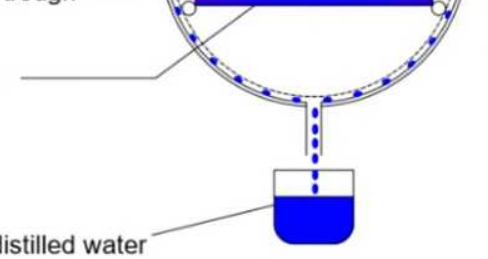

Fig. 1. Schematic diagram and experimental test rig of TSS with fins (left) and without fin (right)

The schematic diagram and experimental test rig photograph of TSS with fins (left) and the TSS without fins (right) is depicted in Fig 1. This experimental setup consists of a transparent tube made up of glass, a steel rectangular water basin called trough and a calibrated flask to collect the freshwater produced. The glass tube allows the penetration of solar irradiance from any direction which helps in augmenting the evaporation process in this desalination system. The trough containing saline water is placed in the transparent glass tube. The trough is coated in black color in order to reduce the refection of solar irradiance by absorbing all the solar irradiance transmitted through the outer transparent glass tube. Solar thermal heat produced by the solar radiation are absorbed by the saline water in the trough. As a result of heating, the 
saline water gets heated and evaporated. The evaporated water vapour get condensed on the inner surface of the glass tube due to the release of latent heat of evaporation. The condensed water flows down by the effect of gravity and collected at the bottom of tube as a freshwater. Two experimental models of TSS in which one of the models having fins attached with trough and another without fins in trough are used and a comparative experimental study between the two models is carried out. Fins used in the trough helps in boosting the desalination process because of the increased surface area of absorber and enhanced greenhouse effect within the still.

\section{Results and discussion}

The experimental data recorded such as solar radiation, ambient temperature, cover, basin, and water temperature from the modified tubular solar still using flat and finned absorber is presented in this section with a detailed discussion. Using the empirical correlations, the instantaneous thermal and exergy efficiencies are determined. In addition to the predicted yield is correlated to the experimental results obtained from the study. Furthermore, a comparison of different solar still using fins, and phase change materials were made to justify the present experimental investigation.

\subsection{Thermal analysis}

In this section, a comparative interpretation between the theoretical and experimental study of TSS with and without fins are carried out. The hourly variation of operating parameters for TSS with and without fins including solar intensity, glass temperature, basin temperature, water temperature and ambient temperature are plotted in graph as shown in Fig. 2 and Fig. 3. Maximum solar intensity of about $963.7 \mathrm{~W} / \mathrm{m}^{2}$ was attained at midday and its starts decreasing gradually. While solar intensity starts decreasing during evening, the temperature of TSS's glass, basin and water starts increasing around evening. The TSS integrated with fins reacts faster and higher to solar intensity than the TSS without fins. The distillate output rate of any solar still is determined by the temperature of water inside still and the performance of still is also depend upon many factors such as air temperature inside still(cavity between the basin and glass cover area), lower glass cover temperature, absorber plate temperature, surface area of absorber etc.,

Fig. 2 shows the solar intensity of TSS without fins are measured starting from 8:00 $\mathrm{AM}-6: 00 \mathrm{PM}$ are presented in the above figure. Solar intensity ranges from $150 \mathrm{~W} / \mathrm{m}^{2}-$ $1000 \mathrm{~W} / \mathrm{m}^{2}$. At the beginning of the day, solar intensity of is about $270 \mathrm{~W} / \mathrm{m}^{2}$ and the temperature is about $20^{\circ} \mathrm{C}$. The ambient, basin, water, glass temperature are about $31,31,29$, 
$16228^{\circ} \mathrm{C}$ and their solar intensity is about $400 \mathrm{~W} / \mathrm{m}^{2}-450 \mathrm{~W} / \mathrm{m}^{2}$.Solar intensity reaches as high as $163963.7 \mathrm{~W} / \mathrm{m}^{2}$ at the noon time and the ambient temperature is about $37.5^{\circ} \mathrm{C}$. The ambient, water, 164 glass temperature reaches its peak at around $3 \mathrm{pm}$ and then gradually decreases, also the solar 165 intensity drops to $150 \mathrm{~W} / \mathrm{m}^{2}$ around 6:00 AM.

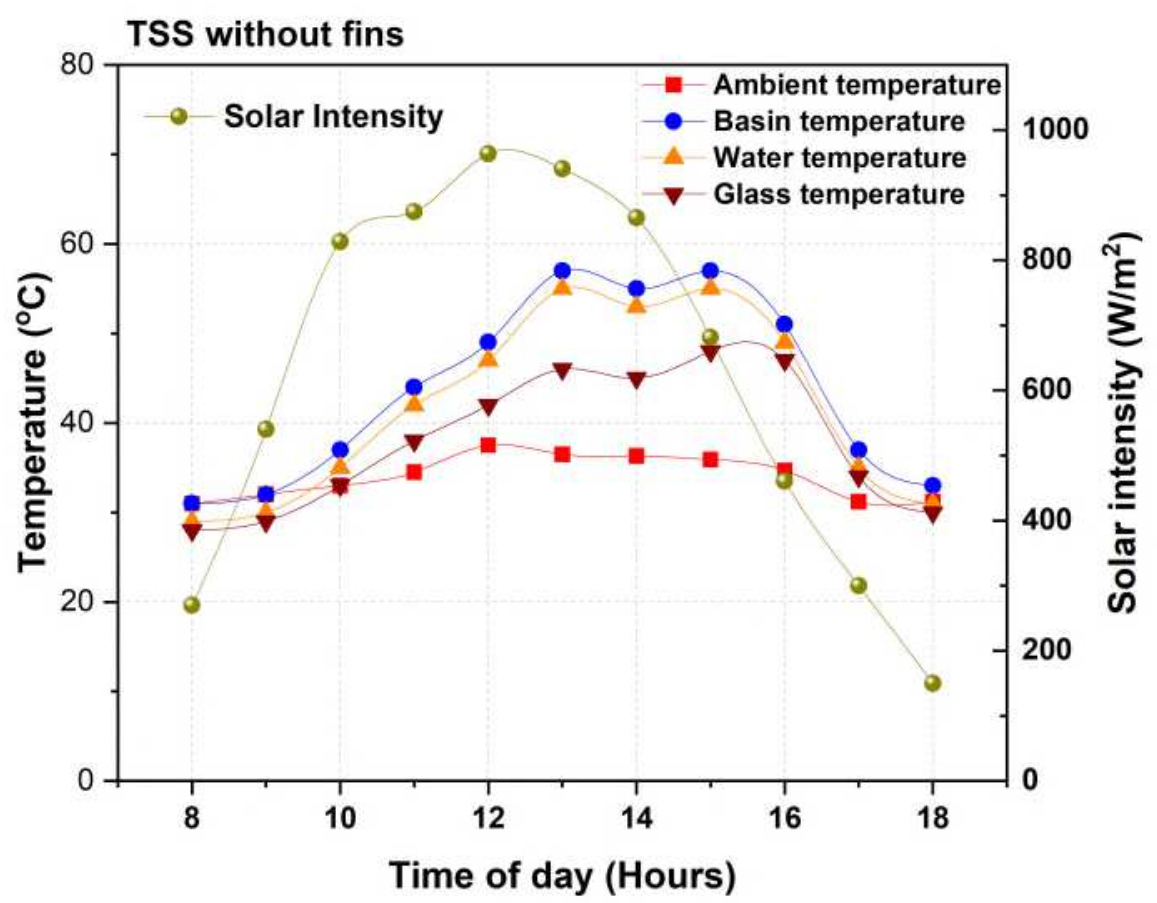




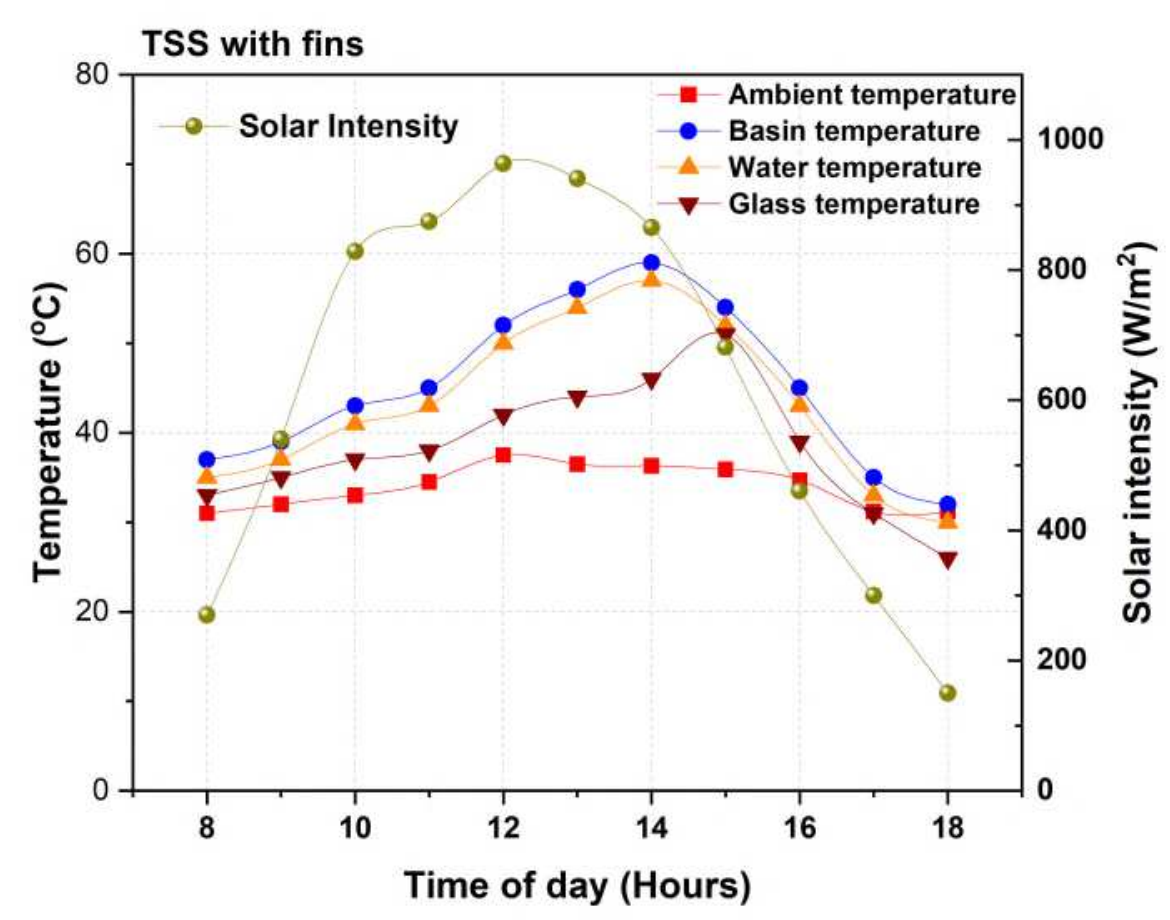

Fig. 3 Hourly variation in solar intensity, ambient, basin, water, and glass temperature recorded from TSS with fins

172 Fig. 3 shows the solar intensity of TSS with fins, the ambient temperature is lower due to lower 173 solar intensity in the day time.so that the basin, water and glass temperature remains lower. 174 The ambient temperature increases from 9:00 AM to 12.00 PM, while the ambient temperature 175 reaches its maximum value of 37.5 around 12:00 PM. The solar intensity increases and reaches 176 a maximum value of $963.7 \mathrm{~W} / \mathrm{m}^{2}$ during the noon. The basin and water temperature attains their 177 maximum temperature around 59 , and57 ${ }^{\circ} \mathrm{C}$ at 2:00 PM. The glass temperature reaches a 178 maximum value of $51{ }^{\circ} \mathrm{C}$ at 3:00 PM. In noon time the ambient temperature decreases to 31.2 $179{ }^{\circ} \mathrm{C}$ so that the solar intensity also decreases and reaches a lower value of $150 \mathrm{~W} / \mathrm{m}^{2}$. Thus, the basin, water and glass temperature also decrease. 


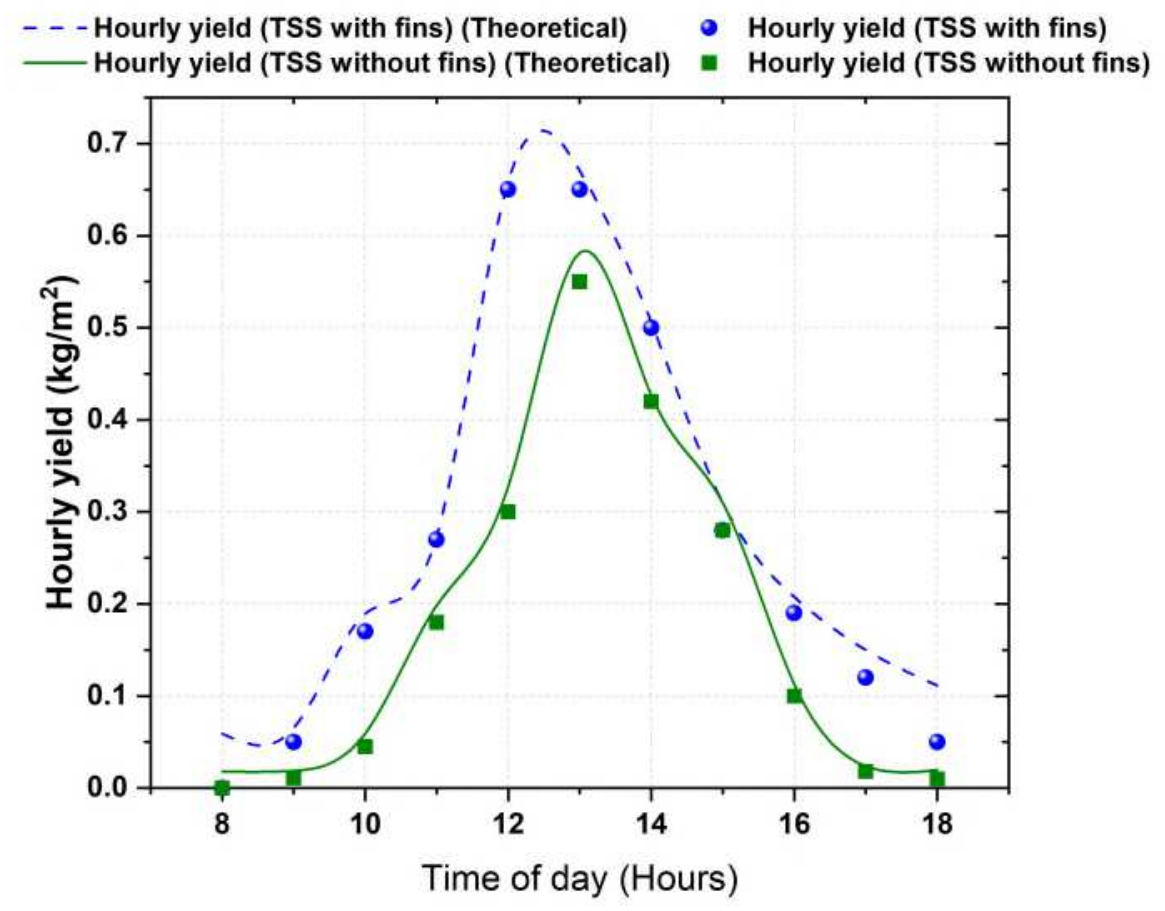

Fig. 4 Hourly variation of theoretical and experimental distillate yield for TSS with and without fins.

The experimental and theoretical results on hourly fresh water production from TSS using flat and finned absorber is plotted in Fig. 4. It is seen from Fig. 4 that using a flat absorber, the hourly fresh water produced is lower as compared to finned absorber. There is a gradual increase in the yield from the sun rise and reaches the maximum during the peak solar intensity. It is also seen that the experimental and theoretical yield are in agreement in both the cases. From the Fig. 4, it is clear that the theoretical distillate yield is always greater than the experimental distillate yield from the TSS. The maximum theoretical freshwater yield value achieved by the TSS with fins is $0.67 \mathrm{~kg} / \mathrm{m}^{2}$ and by the TSS without fins is $0.58 \mathrm{~kg} / \mathrm{m}^{2}$. The maximum experimental freshwater yield value achieved by the TSS with fins is $0.65 \mathrm{~kg} / \mathrm{m}^{2}$ and by the TSS without fins is $0.55 \mathrm{~kg} / \mathrm{m}^{2}$ which shows that the fins present in the TSS will naturally augment the freshwater yield due to the enhanced surface area of absorber. These fins increased the rate of absorption of heat in the basin due to the increased surface area in the basin by the water. The presence of fins in the basin furthermore distributes the heat throughout the water for augmenting the rate of evaporation from the surface of water. With simultaneous increase in the rate of evaporation inside the enclosure, the amount of water produced from the solar still is increased.

Fig. 5 and 6 shows the results of predicted and measured yield of TSS without and with fins on the absorber respectively. The predicted yield from solar still is measured using 
Equation (1) to (3). It can be seen that the experimental yield produced from the TSS in well agreement with the predicted yield with a confidence level of $95 \%$.

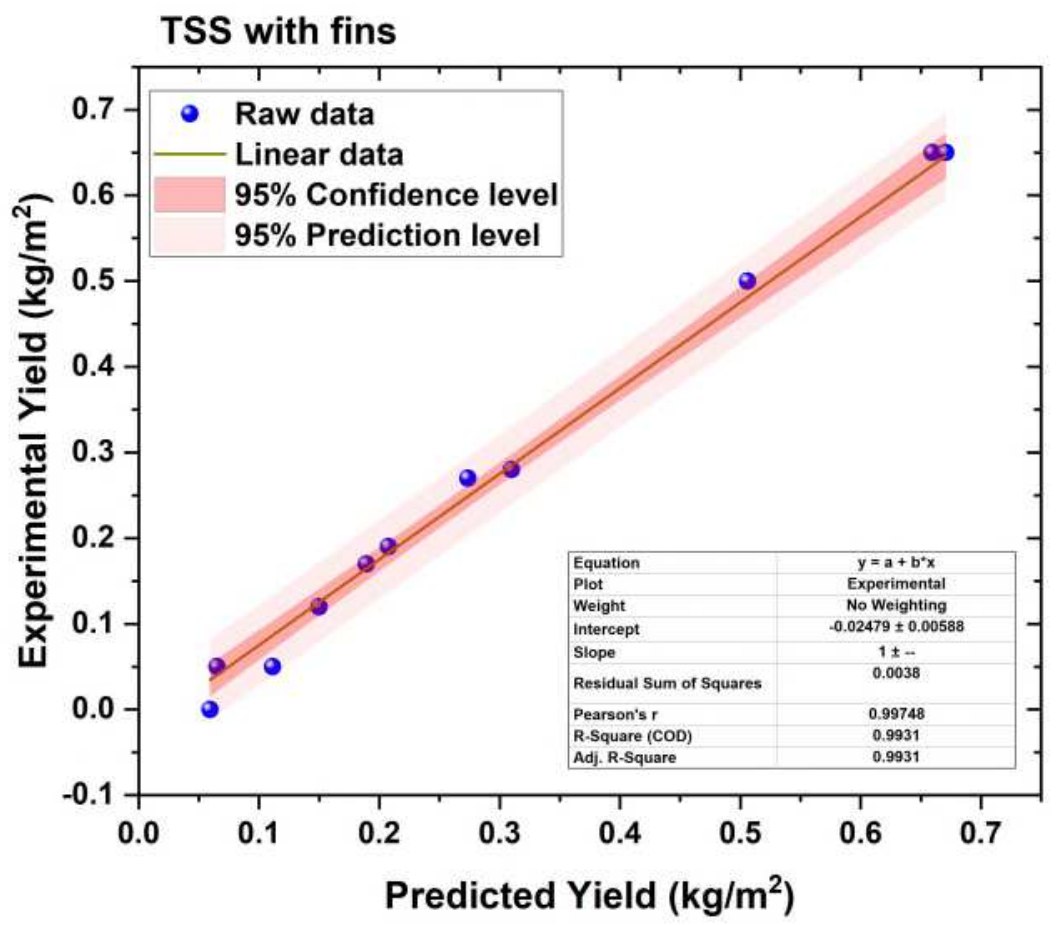

Fig. 5 Predicted and measured yield of TSS with fins

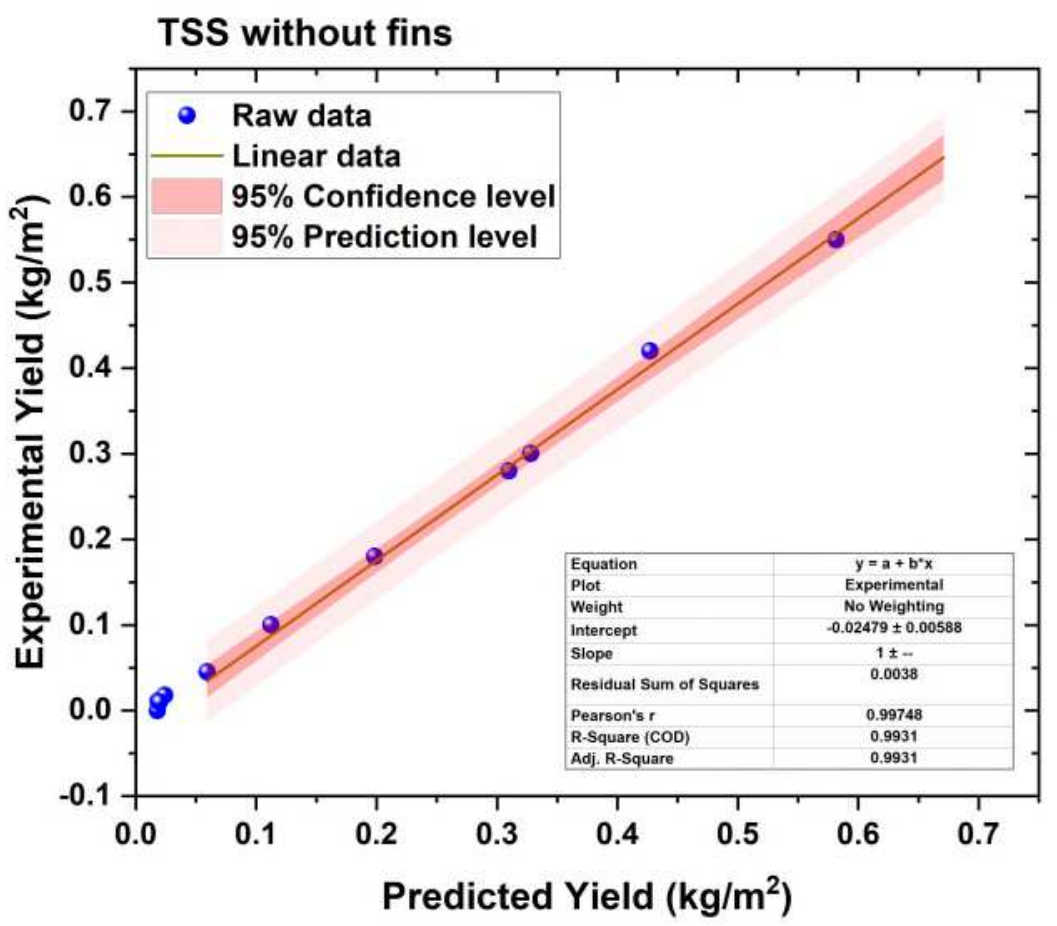


209 The hourly yield from the tubular solar still under both the cases can be mathematically 210 expressed as [43],

$$
m_{e}=\frac{h_{e} \times A_{w} \times\left(T_{w}-T_{g}\right)}{h_{f g}}
$$

212 The influential parameter for determining the yield of fresh water from solar still were partial 213 difference in pressure, evaporative heat transfer coefficient, temperature difference and 214 convective heat transfer coefficient as mathematically expressed in Equation (2) and (3).

215 Mathematically, the EHTC is estimated as (Shukla and Sorayan (2005)),

$$
h_{e}=\frac{16.273 \times 10^{-3} \times h_{c} \times\left(P_{w}-P_{g}\right)}{\left(T_{w}-T_{g}\right)}
$$

217 In the similar way, the CHTC is mathematically expressed as (Shukla and Sorayan (2005)),

$218 h_{c}=0.884\left\{\left(T_{w}-T_{g}\right)+\frac{\left(P_{w}-P_{g}\right)\left(T_{w}+273.15\right)}{\left(268.9 \times 10^{-3}-P_{w}\right)}\right\}^{1 / 3}$ 
Table. 1 Daily yield of different research work done in TSS by various researchers

\begin{tabular}{|c|c|c|c|c|}
\hline S. No & Literature & Study & Fresh water produced & Location \\
\hline 1 & Fath et al (2003) & Pyramid and single slope solar still & $2.6 \mathrm{l} / \mathrm{m}^{2} \mathrm{~d}$ & Aswan, Egypt \\
\hline 2 & Abu-Arabi and Zurigat (2005) & Regenerative solar still & $4.15 \mathrm{~kg} / \mathrm{m}^{2}$ & Marmul, Oman \\
\hline 3 & Arunkumar et al (2013) & Cover cooling of tubular solar still with water and air medium & $5000 \mathrm{ml} / \mathrm{day}$ & Coimbatore, India \\
\hline 4 & Arunkumar et al (2016) & Parabolic concentrators on tubular solar still & $7770 \mathrm{ml} / \mathrm{day}$ & Coimbatore, India \\
\hline 5 & Kabeel et al (2019) & Tubular solar still with cover cooling - effect on water depth & $5.851 / \mathrm{m}^{2}$ & Tanta, Egypt \\
\hline 6 & Elashmawy (2019) & Tubular solar still with cover cooling technique & $2.41 / \mathrm{m}^{2}$ & Hail, Saudi Arabia \\
\hline 7 & Elashmawy (2017) & Tubular solar still with parabolic concentrator & $4.211 / \mathrm{m}^{2}$ & Hail, Saudi Arabia \\
\hline 8 & Panchal (2015) & ETC integrated double slope solar still & - & Patan, India \\
\hline 9 & Panchal \& Thakkar (2016) & ETC integrated solar still & $0.81 \mathrm{~kg}$ & Patan, India \\
\hline 10 & Rahbar et al. (2015) & Computational analysis on tubular solar still - CFD approach & $0.99 \mathrm{~kg} / \mathrm{m}^{2} \mathrm{~h}$ & - \\
\hline 13 & Sarhaddi et al. (2017) & Weir cascaded solar still & $1.08 \mathrm{~kg} / \mathrm{m}^{2} . \mathrm{h}$ & Zahedan,Iran \\
\hline 14 & Shanmugan et al. (2018) & Nano coated absorber plate and PCM & $\begin{array}{l}7.46 \mathrm{~kg} / \mathrm{m}^{2} \text { (summer) } \\
4.12 \mathrm{~kg} / \mathrm{m}^{2} \text { (Winter) }\end{array}$ & Chennai, India \\
\hline 15 & Sharshir et al. (2016) & Continuous desalination using wick and shallow reservoir solar still & $371 /$ day & Kafrelshiekh, Egypt \\
\hline 16 & Taamneh \& Taamneh (2012) & Pyramid type solar still & $2.991 /$ per & Mashad, \\
\hline 17 & Bhaskar \& Rai (2018) & Tubular solar still & $0.168 \mathrm{~L}$ & Allahabad, India \\
\hline 18 & Xie et al (2016) & Multi stage tubular solar still & $0.40 \mathrm{~kg} / \mathrm{hr}$ & Chengdu, China \\
\hline 19 & Panchal \& Mohan (2017) & Methods adopted in finned solar still & $1.05 \mathrm{~kg} / \mathrm{m}^{2} \mathrm{~h}$ & - \\
\hline 20 & Ahsan \& Fukuhara (2010) & Tubular solar still & NA & Fukui, Japan \\
\hline 21 & Rabhi et al (2017) & Pin fins with external condenser & $3.49 \mathrm{~kg} / \mathrm{m} 2$ & Gafsa-Tunisia \\
\hline 22 & El-Sebaii \& El-Naggar (2017) & Finned single slope solar still & $5.4 \mathrm{~kg} / \mathrm{m} 2$ & Tanta, Egypt \\
\hline 23 & El-Sebaii et al (2015) & Fin configuration on solar still & $5.37 \mathrm{~kg} / \mathrm{m} 2$ & Tanta, Egypt \\
\hline 24 & Velmurugan et al (2008) & Single basin solar still with fin for enhancing productivity. & $2.81 \mathrm{~kg} / \mathrm{m} 2$ & Madurai, India \\
\hline 25 & Velmurugan et al (2008a) & Industrial effluent desalination using fins in solar still & $2.77 \mathrm{~kg} / \mathrm{m} 2$ & Madurai, India \\
\hline 26 & Rajaseenivasan \& Srithar (2016) & $\mathrm{CO} 2$ mitigation on solar still using square and circular fins & $4.55 \mathrm{~kg} / \mathrm{m} 2$ & Madurai, India \\
\hline 27 & Alaian et al. (2016) & Pin fins and wick inside single slope solar still & $4820 \mathrm{ml} / \mathrm{m} 2$ & Mansoura, Egypt \\
\hline 28 & Manokar et al. (2017) & Acrylic solar still with pin fins & $2.64 \mathrm{~kg} / \mathrm{m} 2$ & Chennai, India \\
\hline
\end{tabular}




\begin{tabular}{|l|l|l|l|l|}
\hline 29 & $\begin{array}{l}\text { Muthu Manokar \& Prince } \\
\text { Winston (2017) }\end{array}$ & $\begin{array}{l}\text { Comparative analysis on galvanized iron and Acrylic solar still with } \\
\text { pin fins }\end{array}$ & $2.34 \mathrm{~kg} / \mathrm{m} 2$ \\
\hline 30 & $\begin{array}{l}\text { Panomwan Na Ayuthaya, R.t al } \\
(2013)\end{array}$ & $\begin{array}{l}\text { The thermal performance of an ethanol solar still with fin plate to } \\
\text { increase productivity. }\end{array}$ & $3.5 \mathrm{~kg} / \mathrm{m} 2$ \\
\hline 31 & Jani \& Modi (2018) & Circular and square hollow fins in single slope solar still & $\begin{array}{l}1.49 \mathrm{~kg} / \mathrm{m} 2(\mathrm{circular} \\
\text { fin) } \\
0.94 \mathrm{~kg} / \mathrm{m} 2(\mathrm{square} \\
\text { fin) }\end{array}$ & $\begin{array}{l}\text { Valsad, India } \\
7 \mathrm{~kg} / \mathrm{m} 2\end{array}$ \\
\hline 32 & Srivastava \& Agrawal (2013) & Single slope solar still with extended porous fins & $3.9 \mathrm{~kg} / \mathrm{m} 2$ \\
\hline 33 & Yousef et al (2019) & Pin fin heat sink PCM based energy storage in solar still & Alexandria, Egypt \\
\hline 34 & Appadurai \& Velmurugan (2015) & Solar pond integrated solar still & 3 & $3.5 \mathrm{~kg} / \mathrm{m} 2$ \\
\hline 35 & Omara et al. (2011) & Corrugated absorber single slope solar still & NA & Kafrelshiekh, Egypt \\
\hline
\end{tabular}




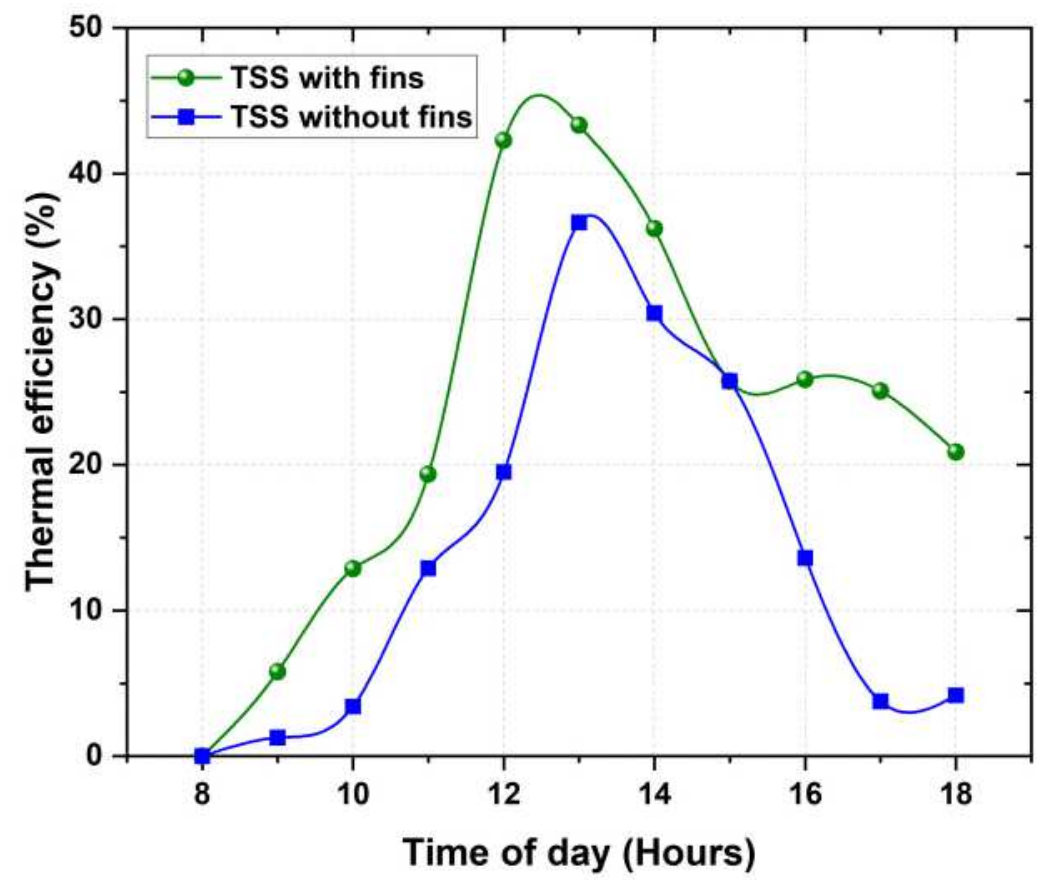

Fig. 7 Instantaneous variations in thermal efficiency of TSS with and without fins.

The instantaneous hourly changes in thermal efficiency of the TSS using flat absorber and finned absorber is plotted in Fig. 7. The instantaneous thermal efficiency of the solar still is calculated using Equation (4) and as follows,

$$
\text { Instantaneous Thermal efficiency, } \eta_{\text {thermal }}=\frac{m_{e} \times h_{f g}}{I(t) \times A_{w} \times 3600} \times 100
$$

From the graph, it can be noted that the efficiency of the solar still without fins reaches the peak value during mid-day and gradually falls around evening. The thermal efficiency of the TSS having fins also reaches the maximum value during the mid-day same as the solar still without fans but the TSS with fins maintains the thermal efficiency for a significant time period in evening of that experiment day. The peak value of thermal efficiency for solar still without fins reached approximately $36.65 \%$, whereas for the solar still with fins it attains a peak value of about $43.13 \%$. Hence, the usage of fins in the TSS has a remarkable effect on the freshwater production and also helps in boosting the vapor to entrap inside the tubular enclosure.

\subsection{Rate of irreversibility from water, glass and basin}

The rate of irreversibility of water, glass and basin using finned absorber and flat absorber is mathematically expressed in Equation (5-7). The total rate of irreversibility is the summation of destruction of exergy and loss of exergy.

The rate of irreversibility from glass is mathematically given as (Sarhaddi et al. (2017)), 


$$
I_{r, g}=\alpha_{g} E_{\text {sun }}+U_{b} \times\left(T_{b}-T_{w}\right)\left(1-\frac{T_{a}}{T_{b}}\right)
$$

The rate of irreversibility from water is mathematically given as (Sarhaddi et al. (2017)),

$$
I_{r, g}=\tau_{g} \alpha_{w} E_{\text {sun }}+U_{b} \times\left(T_{b}-T_{w}\right)\left(1-\frac{T_{a}}{T_{b}}\right)-E_{\text {evap }}
$$

The rate of irreversibility from basin is mathematically given as (Sarhaddi et al. (2017)),

$$
I_{r, g}=\tau_{g} \tau_{w} \alpha_{b} E_{\text {sun }}+U_{b} \times\left(T_{b}-T_{w}\right)\left(1-\frac{T_{a}}{T_{b}}\right)
$$

Fig. 8 (a, b) shows the variations of irreversibility of water, glass, and basin of water, glass and basin of TSS using flat and finned absorber. It is clear that the irreversibility of basin is higher in both the case and the lower irreversibility occurs on water and glass. Also, on increased solar intensity falling on the solar still increased the irreversibility of each component. The average irreversibility rate of water, glass and basin using flat absorber is found as 26.45, 29.45 and $457.2 \mathrm{~W}$ respectively, whereas, for a finned absorber it is found as $24.6,29.02$ and $448.8 \mathrm{~W}$ respectively. It is observed that the irreversibility rate of finned absorber is reduced as compared to that of solar still using flat absorber. Also, from Fig. 8 (a) and (b) it is depicted that the irreversibility rate of water and glass were closer till reaching the peak solar intensity. From the previous literatures (Sarhaddi et al. (2017)) it is found that the irreversibility of solar still can be reduced by modifying the design of the absorber plate.
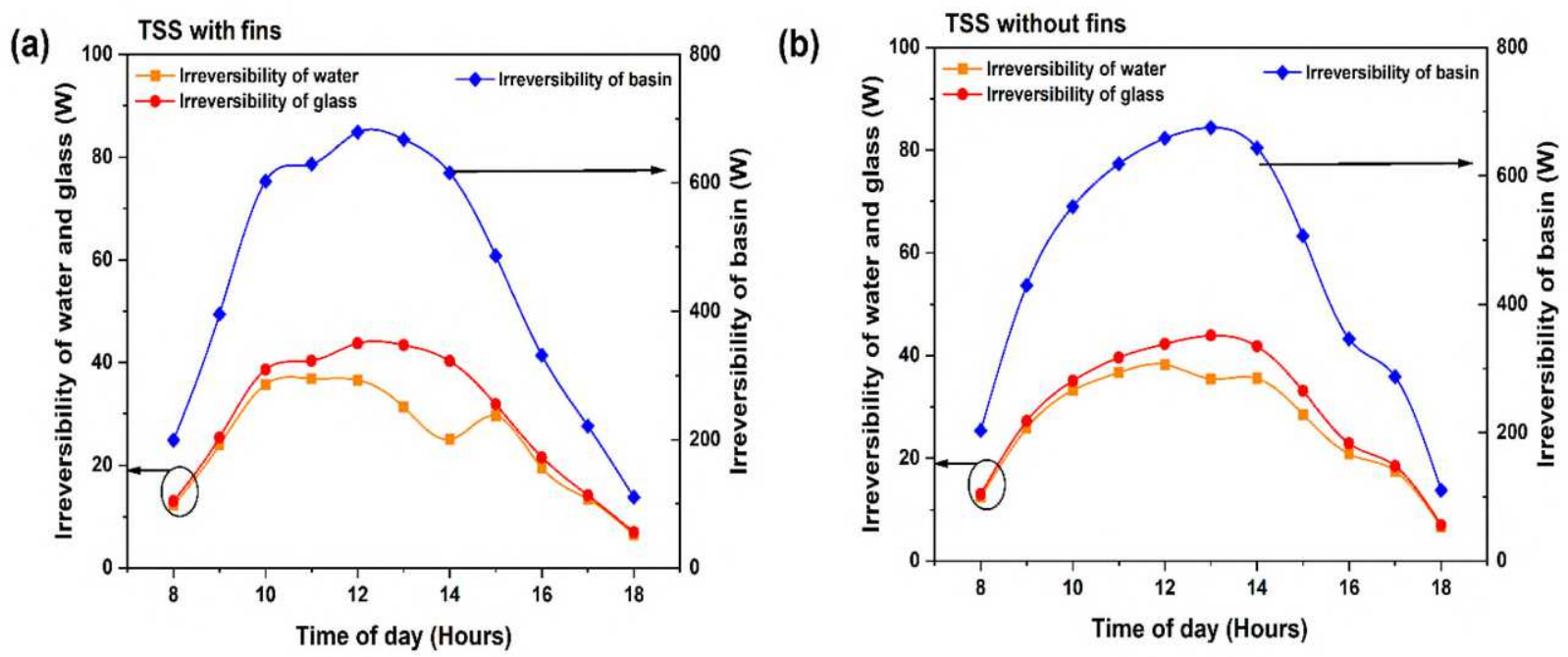

Fig. 8 Irreversibility of water, glass, and basin of TSS using (a) flat absorber and (b) finned absorber

\subsection{Exergy efficiency}

The exergy efficiency of the solar still is mathematically expressed as follows (Petla (2003); Hepbasli (2008)),

$$
\eta_{\text {exergy efficiency }}=\frac{E_{\text {out }}}{E_{\text {in }}} \times 100
$$


The exergy output is mathematically expressed as (Petla (2003); Hepbasli (2008)),

$$
E_{\text {out }}=E_{\text {evaporation }}=\frac{m_{e}}{3600} \times A_{w} \times h_{f g} \times\left(1-\frac{T_{a}}{T_{w}}\right)
$$

268 Where,

$\mathrm{h}_{\mathrm{fg}}$ - Latent heat of vaporization $(\mathrm{kJ} / \mathrm{kg})$

$\mathrm{T}_{\mathrm{w}}$ - Water temperature $(\mathrm{K})$

272

The exergy input is mathematically expressed as (Petla (2003); Hepbasli (2008)),

$$
E_{\text {in }}=E_{\text {sun }}=A_{w} \times I(t) \times\left[1-\frac{4}{3}\left(\frac{T_{a}}{T_{\text {sun }}}\right)+\frac{1}{3}\left(\frac{T_{a}}{T_{\text {sun }}}\right)^{4}\right]
$$

273

Where,

$$
\mathrm{T}_{\text {sun- }} \text { Temperature of sun }\left(\mathrm{T}_{\text {sun }}=6000 \mathrm{~K}\right)
$$

$\mathrm{T}_{\mathrm{a}}$ - ambient temperature $(\mathrm{K})$

The exergy efficiency of the solar still increases with respect to time and the amount of solar radiation falling on the system. It is seen that the exergy efficiency of the both the solar still increases as the solar radiation increased and reaching the maximum of 11.8 and $10.6 \%$ for finned and flat absorber respectively. During the start of experiment till reaching the maximum solar intensity the exergy efficiency of finned absorber TSS produced exergy efficiency.

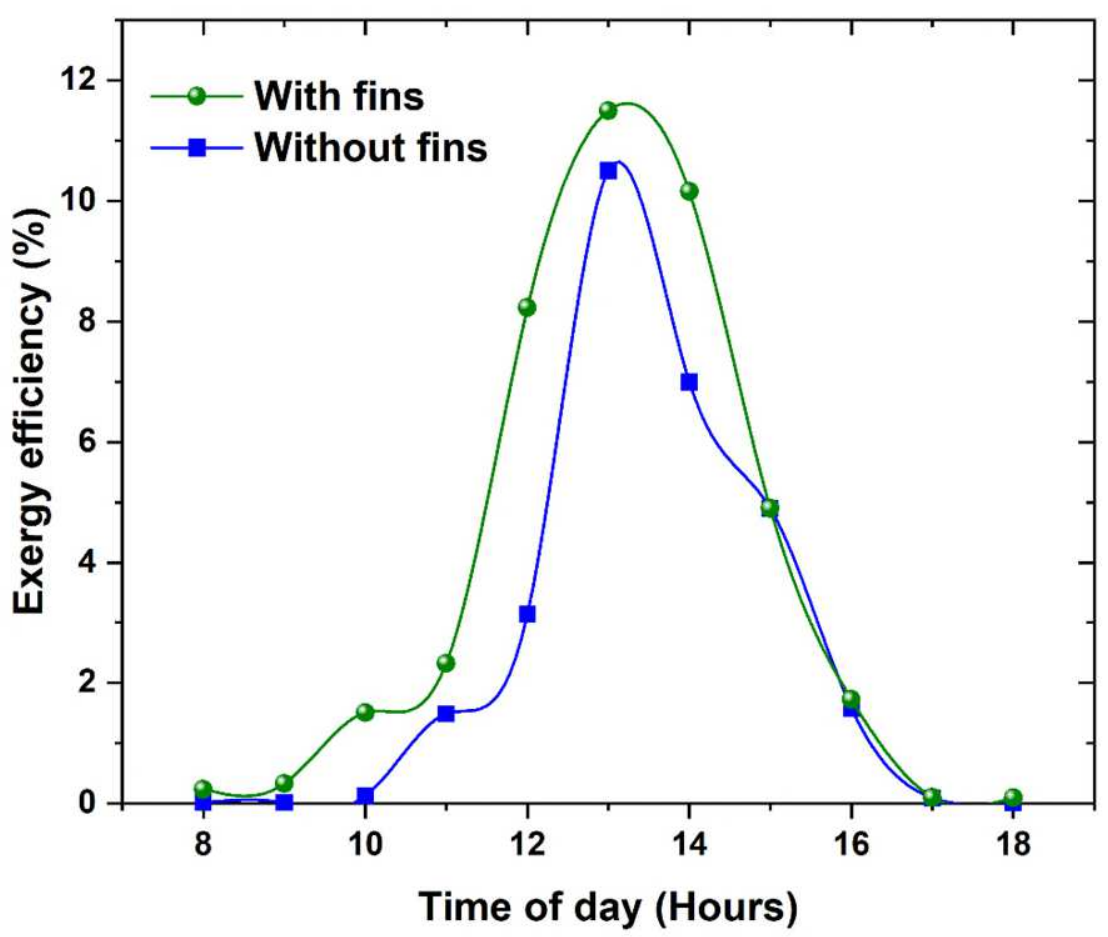

Fig. 9 Instantaneous variations on exergy efficiency from TSS using flat and finned absorber

\section{Conclusions}



The findings of experimental and theoretical study show that the fins integrated with the basin of TSS augmented the performance and thermal efficiency higher than the TSS without fins. The distillate yield of TSS with fins is experimentally and theoretically higher than the TSS without fins. A cumulative distillate gain of $53.08 \%$ implying an hourly thermal efficiency gain of $69.9 \%$ are recorded for the TSS with fins compared with the TSS without fins. The maximum daily distillate production has been found to be 2.931 per day for TSS with fins. The use of fins in the basin of TSS enhanced the amount of heat absorbed by the absorber due to increase in the surface area of absorber plate which in turn results in the higher freshwater production compared to the TSS without fins. The rate of irreversibility is slightly reduced from the TSS using finned absorber while compared to the flat absorber. Similarly, by attaching fins in the absorber plate, the exergy efficiency is improved from the solar still while compared to solar still with flat absorber.

Ethical Approval

Not Applicable

\section{Consent to Participate}

301

Not Applicable

\section{Consent to Publish}

Not Applicable

\section{Authors Contributions}

Conceptualization, Methodology, Resources, Formal analysis, Writing - original draft preparation, review and editing, Supervision and investigation were carried out by Ravishankar Sathyamurthy, Abd Elnaby Kabeel, Ali Chamkha

Writing - original draft preparation, review and editing were carried out by Hemanth Arun Kumar, Hariprasath Venkateswaran, Athikesavan Muthu Manokar, Ramani Bharathwaaj, Sathiyaseelan Vasanthaseelan

\section{$311 \quad$ Funding}

312 There is no funding received for the research work carried out. 
The authors declare that there is no competing interest

\section{Availability of data and materials}

Not Applicable

\section{Reference:}

Abdelgaied, M., Kabeel, A. E., \& Sathyamurthy, R. (2020). Improving the performance of solar powered membrane distillation systems using the thermal energy storage mediums and the evaporative cooler. Renewable Energy.

Abu-Arabi, M., \& Zurigat, Y. (2005). Year-round comparative study of three types of solar desalination units. Desalination, 172(2), 137-143.

Ahsan, A., \& Fukuhara, T. (2010). Mass and heat transfer model of tubular solar still. Solar energy, 84(7), 1147-1156.

Alaian, W.M., Elnegiry, E.A., Hamed, A.M., 2016. Experimental investigation on the performance of solar still augmented with pin-finned wick. Desalination 379, 10-15.

Appadurai, M., Velmurugan, V., 2015. Performance analysis of fin type solar still integrated with fin type mini solar pond. Sustain. Energy Technol. Assess. 9, 30-36.

Arunkumar, T., Jayaprakash, R., Ahsan, A., Denkenberger, D., \& Okundamiya, M. S. (2013). Effect of water and air flow on concentric tubular solar water desalting system. Applied energy, 103, 109115 .

Arunkumar, T., Velraj, R., Denkenberger, D. C., Sathyamurthy, R., Kumar, K. V., \& Ahsan, A. (2016). Productivity enhancements of compound parabolic concentrator tubular solar stills. Renewable energy, 88, 391-400.

Attia, M. E. H., Driss, Z., Abdelgaied, M., Manokar, A. M., Sathyamurthy, R., \& Hussein, A. K. (2021). Performance Evaluation of Modified Solar Still Using Aluminum Foil Sheet as Absorber Cover-A Comparative Study. Journal of Testing and Evaluation, 49(5).

Attia, M. E. H., Driss, Z., Manokar, A. M., \& Sathyamurthy, R. (2020). Effect of aluminum balls on the productivity of solar distillate. Journal of Energy Storage, 30, 101466.

Balachandran, G. B., David, P. W., Rajendran, G., Ali, M. N. A., Radhakrishnan, V., Balamurugan, R., ... \& Sathyamurthy, R. (2020). Investigation of performance enhancement of solar still incorporated with Gallus gallus domesticus cascara as sensible heat storage material. Environmental Science and Pollution Research, 1-14.

Bhaskar, N., \& Rai, A. K. (2018). Thermal investigation of a tubular solar still. Technology, 9(1), 356362.

Elashmawy, M. (2017). An experimental investigation of a parabolic concentrator solar tracking system integrated with a tubular solar still. Desalination, 411, 1-8. 
Elashmawy, M. (2019). Effect of surface cooling and tube thickness on the performance of a high temperature standalone tubular solar still. Applied Thermal Engineering, 156, 276-286.

El-Sebaii, A. A., \& El-Naggar, M. (2017). Year round performance and cost analysis of a finned single basin solar still. Applied Thermal Engineering, 110, 787-794.

El-Sebaii, A.A., Ramadan, M.R.I., Aboul-Enein, S., El-Naggar, M., 2015. Effect of fin configuration parameters on single basin solar still performance. Desalination 365, 15-24.

Essa, F. A., Elsheikh, A. H., Algazzar, A. A., Sathyamurthy, R., Ali, M. K. A., Abd Elaziz, M., \& Salman, K. H. (2020). Eco-friendly coffee-based colloid for performance augmentation of solar stills. Process Safety and Environmental Protection, 136, 259-267.

Fath, H. E., El-Samanoudy, M., Fahmy, K., \& Hassabou, A. (2003). Thermal-economic analysis and comparison between pyramid-shaped and single-slope solar still configurations. Desalination, 159(1), 69-79.

Hepbasli, A. (2008). A key review on exergetic analysis and assessment of renewable energy resources for a sustainable future. Renewable and sustainable energy reviews, 12(3), 593-661.

Jani, H.K., Modi, K.V., 2018. Experimental performance evaluation of single basin dual slope solar still with circular and square cross-sectional hollow fins. Sol. Energy 179 (December), 186-194, 2019.

Kabeel, A. E., Sharshir, S. W., Abdelaziz, G. B., Halim, M. A., \& Swidan, A. (2019). Improving performance of tubular solar still by controlling the water depth and cover cooling. Journal of cleaner production, 233, 848-856.

Kumar, S. A., Kumar, P. S. M., Sathyamurthy, R., \& Manokar, A. M. (2020). A study of life cycle conversion efficiency and $\mathrm{CO} 2$ role in the pyramid shape solar stills-Comparative analysis. Groundwater for Sustainable Development, 100413.

Manokar, A.M., Winston, D.P., 2017. Experimental analysis of single basin single slope finned acrylic solar still. Mater. Today Proc. 4 (8), 7234-7239.

Muthu Manokar, A., Prince Winston, D., 2017. Comparative study of finned acrylic solar still and galvanised iron solar still. Mater. Today Proc. 4 (8), 8323-8327.

Muthu Manokar, A., Vimala, M., Prince Winston, D., Rajendran, D. R., Sathyamurthy, R., \& Kabeel, A. E. (2020). Year around distilled water production, energy, and economic analysis of solar stills-A comparative study. Heat Transfer, 49(6), 3651-3662.

Muthu Manokar, A., Vimala, M., Prince Winston, D., Rajendran, D. R., Sathyamurthy, R., \& Kabeel, A. E. (2020). A comparative study of 3E (energy, exergy, and economy) analysis of various solar stills. Heat Transfer, 49(8), 4394-4409.

Omara, Z.M., Hamed, M.H., Kabeel, A.E., 2011. Performance of finned and corrugated absorbers solar stills under Egyptian conditions. Desalination 277 (1-3), 281-287.

Panchal, H. N. (2015). Enhancement of distillate output of double basin solar still with vacuum tubes. Journal of King Saud University-Engineering Sciences, 27(2), 170-175. 
Panchal, H. N., \& Thakkar, H. (2016). Theoretical and experimental validation of evacuated tubes directly coupled with solar still. Thermal Engineering, 63(11), 825-831.

Panchal, H., \& Mohan, I. (2017). Various methods applied to solar still for enhancement of distillate output. Desalination, 415, 76-89.

Panomwan Na Ayuthaya, R., Namprakai, P., Ampun, W., 2013. The thermal performance of an ethanol solar still with fin plate to increase productivity. Renew. Energy 54, 227-234.

Petela, R. (2003). Exergy of undiluted thermal radiation. Solar energy, 74(6), 469-488.

Rabhi, K., Nciri, R., Nasri, F., Ali, C., Ben Bacha, H., 2017. Experimental performance analysis of a modified single-basin single-slope solar still with pin fins absorber and condenser. Desalination 416 (April), 86-93.

Rahbar, N., Esfahani, J. A., \& Fotouhi-Bafghi, E. (2015). Estimation of convective heat transfer coefficient and water-productivity in a tubular solar still-CFD simulation and theoretical analysis. Solar Energy, 113, 313-323.

Rajaseenivasan, T., Srithar, K., 2016. Performance investigation on solar still with circular and square fins in basin with CO2 mitigation and economic analysis. Desalination 380 (January), 66-74.

Sarhaddi, F., Tabrizi, F. F., Zoori, H. A., \& Mousavi, S. A. H. S. (2017). Comparative study of two weir type cascade solar stills with and without PCM storage using energy and exergy analysis. Energy Conversion and Management, 133, 97-109.

Shanmugan, S., Palani, S., \& Janarthanan, B. (2018). Productivity enhancement of solar still by PCM and Nanoparticles miscellaneous basin absorbing materials. Desalination, 433, 186-198.

Sharshir, S. W., Eltawil, M. A., Algazzar, A. M., Sathyamurthy, R., \& Kandeal, A. W. (2020). Performance enhancement of stepped double slope solar still by using nanoparticles and linen wicks: Energy, exergy and economic analysis. Applied Thermal Engineering, 115278.

Sharshir, S. W., Peng, G., Yang, N., El-Samadony, M. O. A., \& Kabeel, A. E. (2016). A continuous desalination system using humidification-dehumidification and a solar still with an evacuated solar water heater. Applied Thermal Engineering, 104, 734-742.

Shukla, S. K., \& Sorayan, V. P. S. (2005). Thermal modeling of solar stills: an experimental validation. Renewable Energy, 30(5), 683-699.

Srivastava, P.K., Agrawal, S.K., 2013. Winter and summer performance of single sloped basin type solar still integrated with extended porous fins. Desalination 319, 73-78.

Taamneh, Y., \& Taamneh, M. M. (2012). Performance of pyramid-shaped solar still: Experimental study. Desalination, 291, 65-68.

Velmurugan, V., Deenadayalan, C.K., Vinod, H., Srithar, K., 2008a. Desalination of effluent using fin type solar still. Energy 33 (11), 1719-1727.

Velmurugan, V., Gopalakrishnan, M., Raghu, R., Srithar, K., 2008. Single basin solar still with fin for enhancing productivity. Energy Convers. Manag. 49 (10), 2602-2608. 
422 Xie, G., Sun, L., Mo, Z., Liu, H., \& Du, M. (2016). Conceptual design and experimental investigation involving a modular desalination system composed of arrayed tubular solar stills. Applied energy, 179, 972-984.

Yousef, M.S., Hassan, H., Kodama, S., Sekiguchi, H., 2019. An experimental study on the performance of single slope solar still integrated with a PCM-based pin-finned heat sink. Energy Procedia 156 (September), 100-104, 2018.

428

Zurigat, Y. H., \& Abu-Arabi, M. K. (2004). Modelling and performance analysis of a regenerative solar desalination unit. Applied thermal engineering, 24(7), 1061-1072. 
Figures
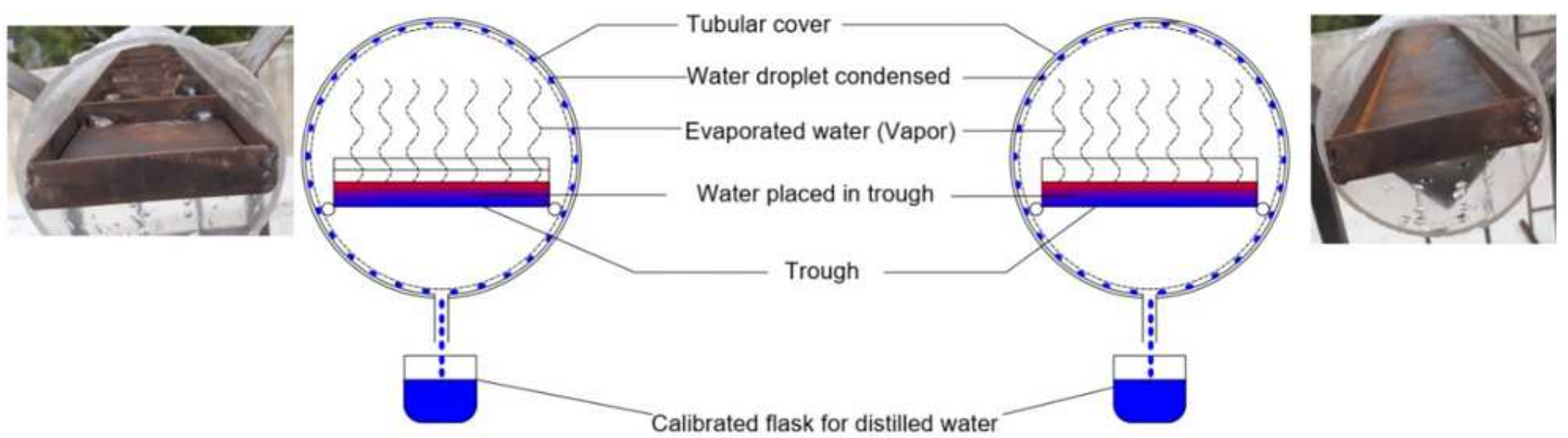

Figure 1

Schematic diagram and experimental test rig of TSS with fins (left) and without fin (right)

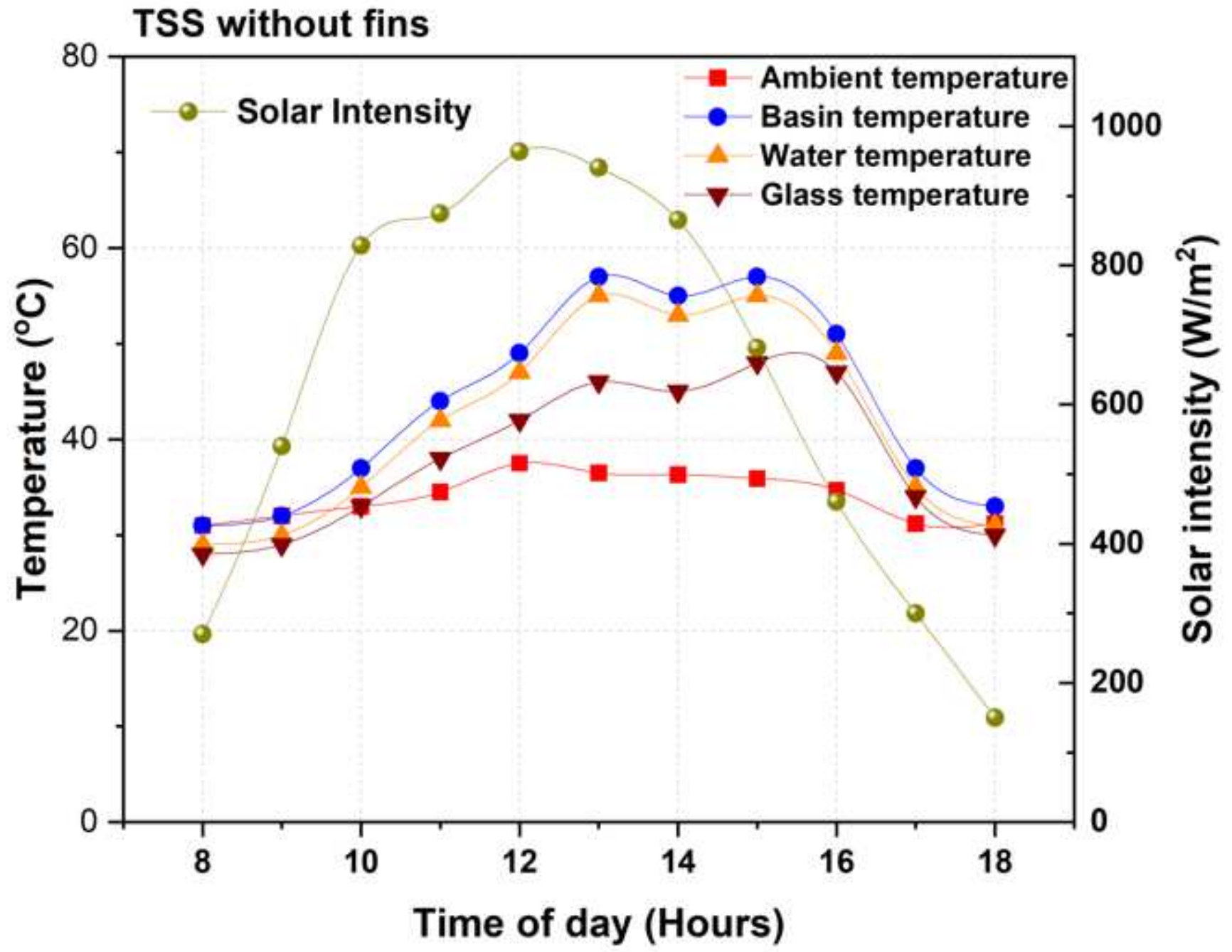


Figure 2

Hourly variation in solar intensity, ambient, basin, water, and glass temperature recorded from TSS without fins

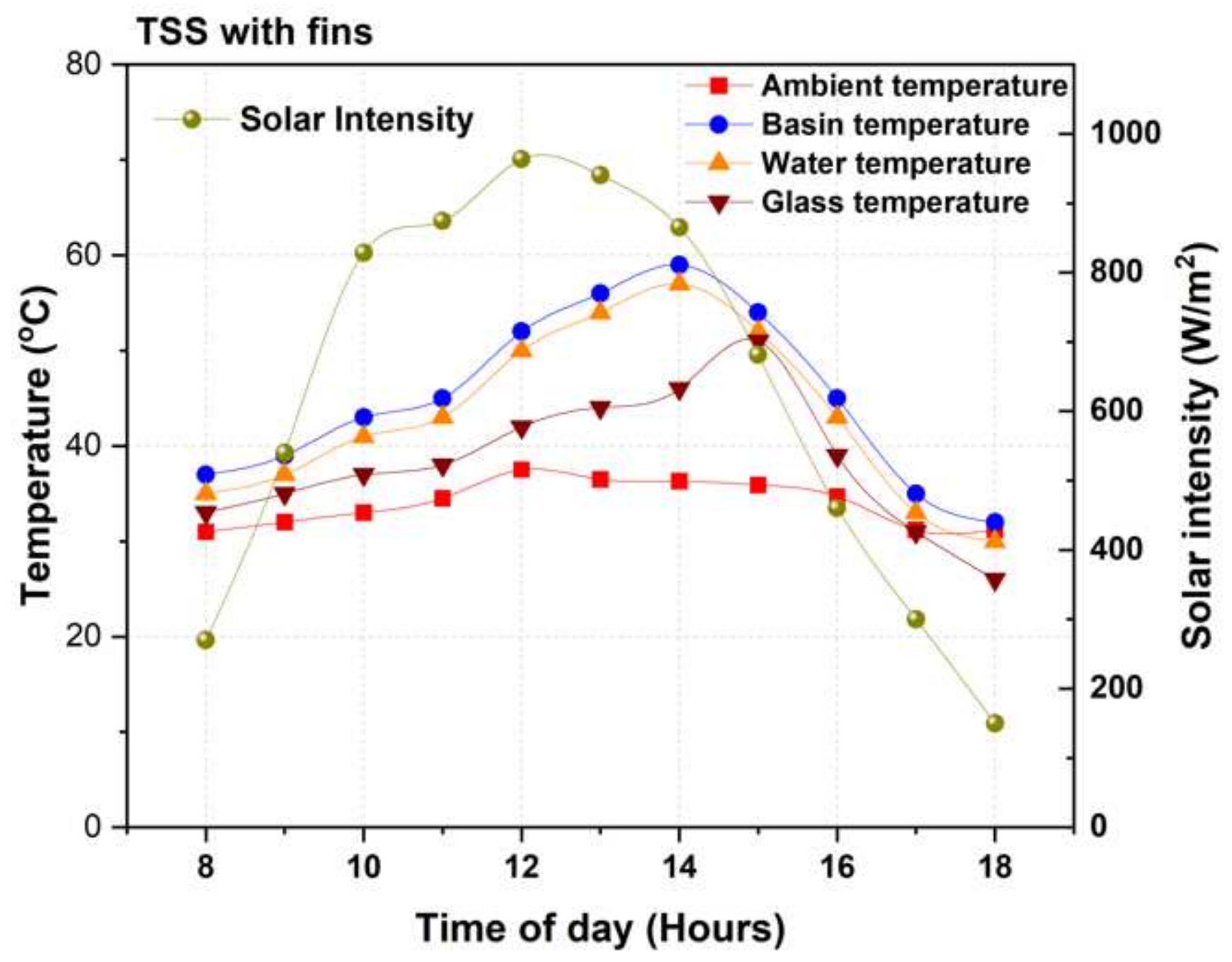

Figure 3

Hourly variation in solar intensity, ambient, basin, water, and glass temperature recorded from TSS with fins 
-- Hourly yield (TSS with fins) (Theoretical)
- Hourly yield (TSS without fins) (Theoretical)

- Hourly yield (TSS with fins)

Figure 4

Hourly variation of theoretical and experimental distillate yield for TSS with and without fins. 
TSS with fins

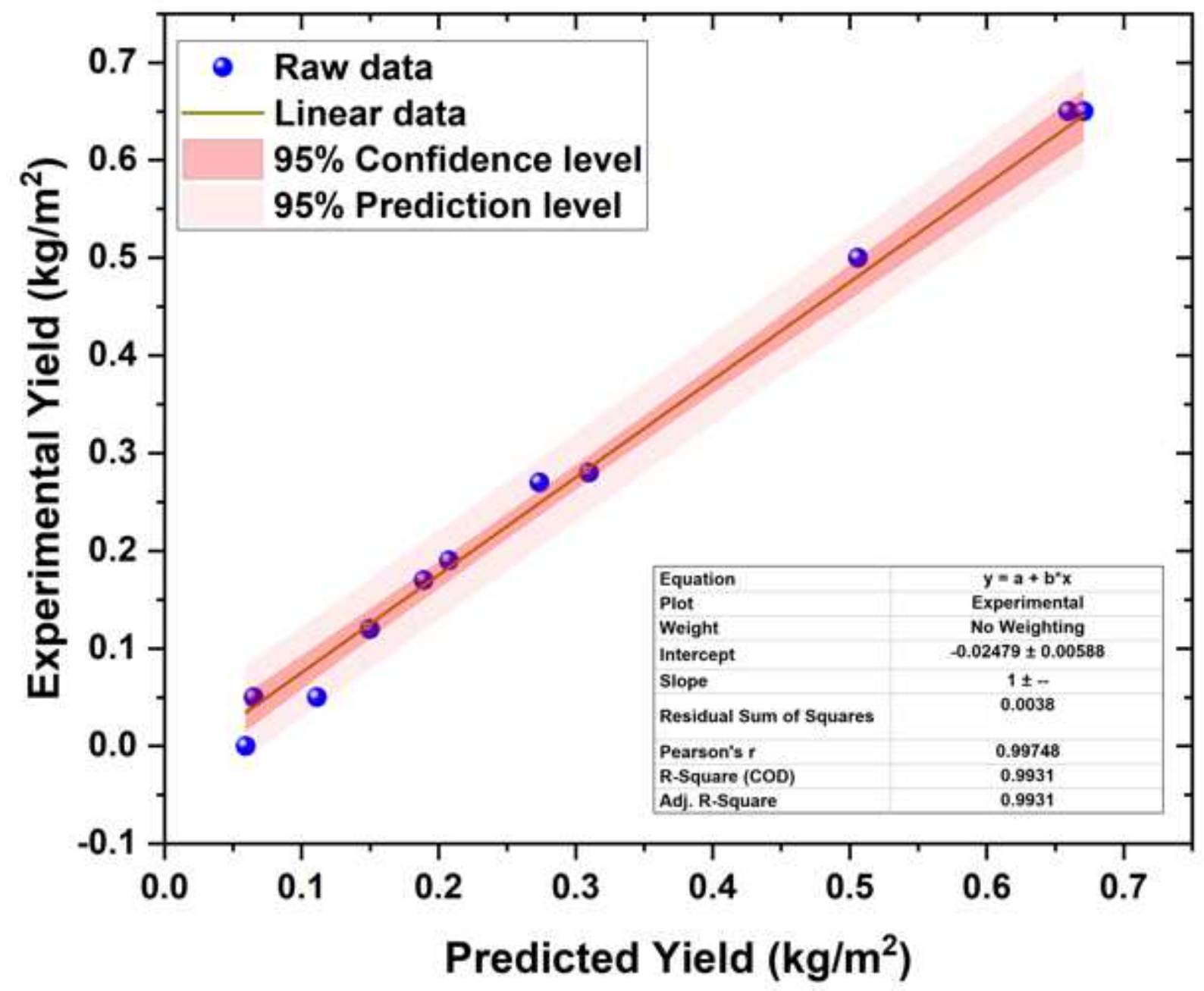

Figure 5

Predicted and measured yield of TSS with fins 


\section{TSS without fins}

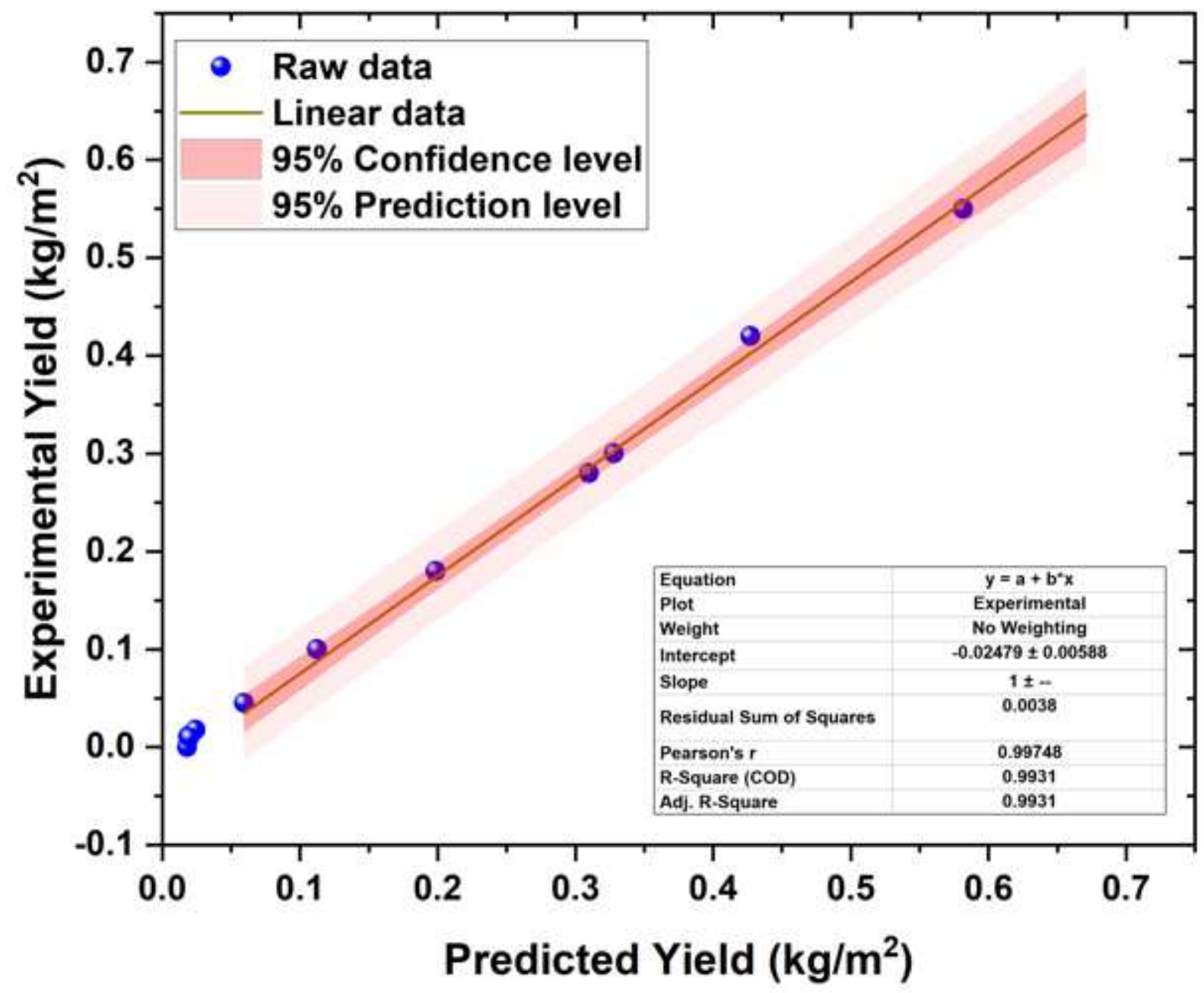

Figure 6

Predicted and measured yield of TSS without fins 


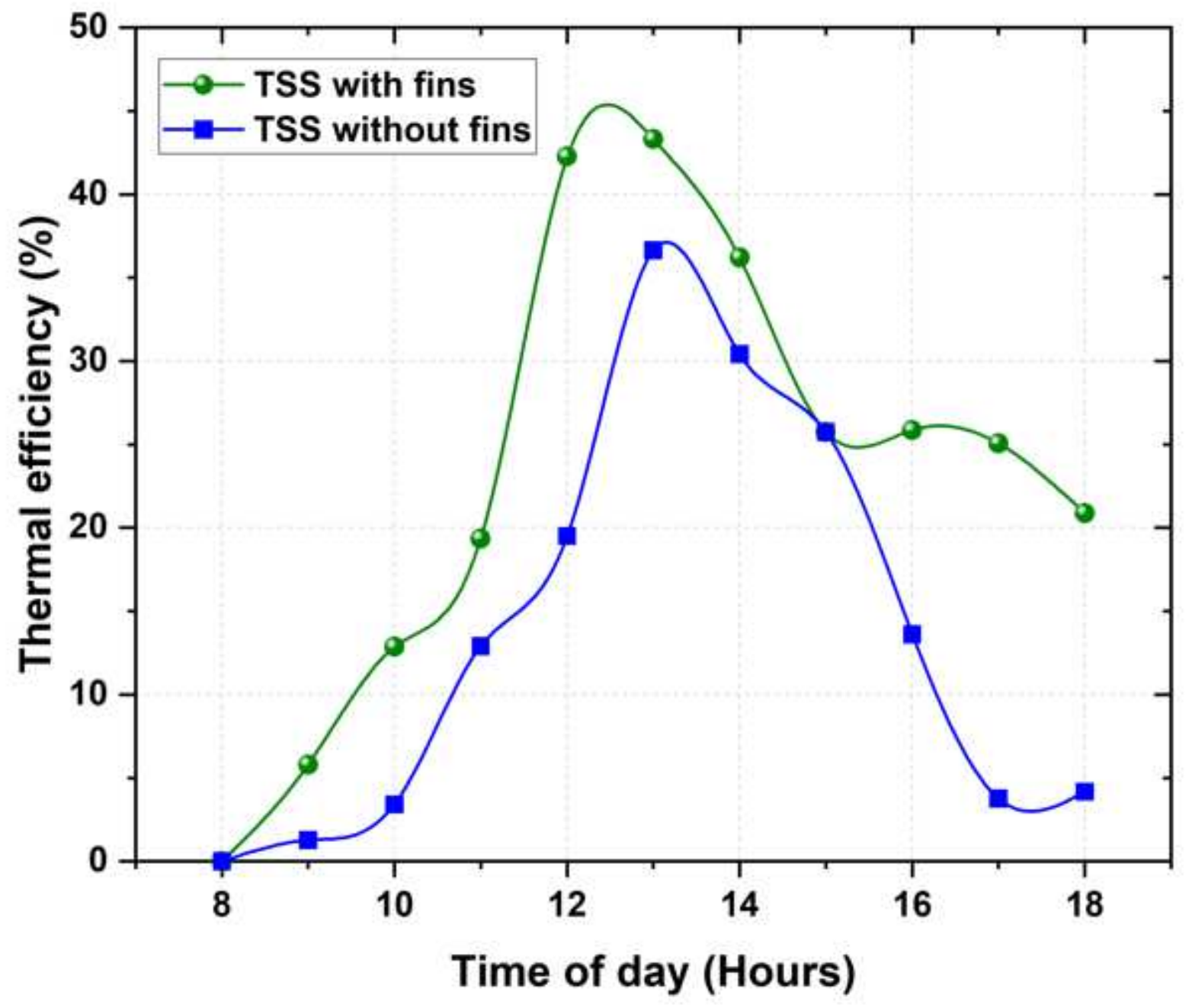

Figure 7

Instantaneous variations in thermal efficiency of TSS with and without fins.
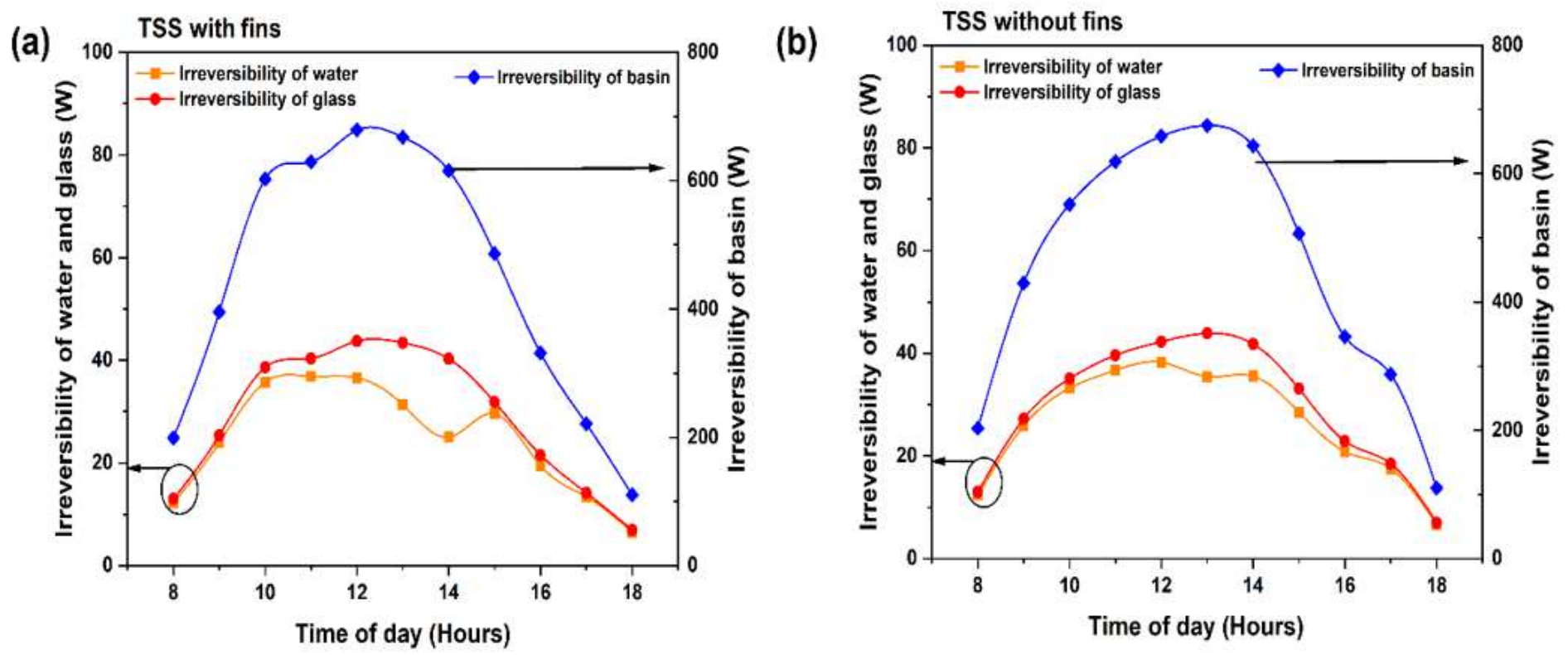

Figure 8 
Irreversibility of water, glass, and basin of TSS using (a) flat absorber and (b) finned absorber

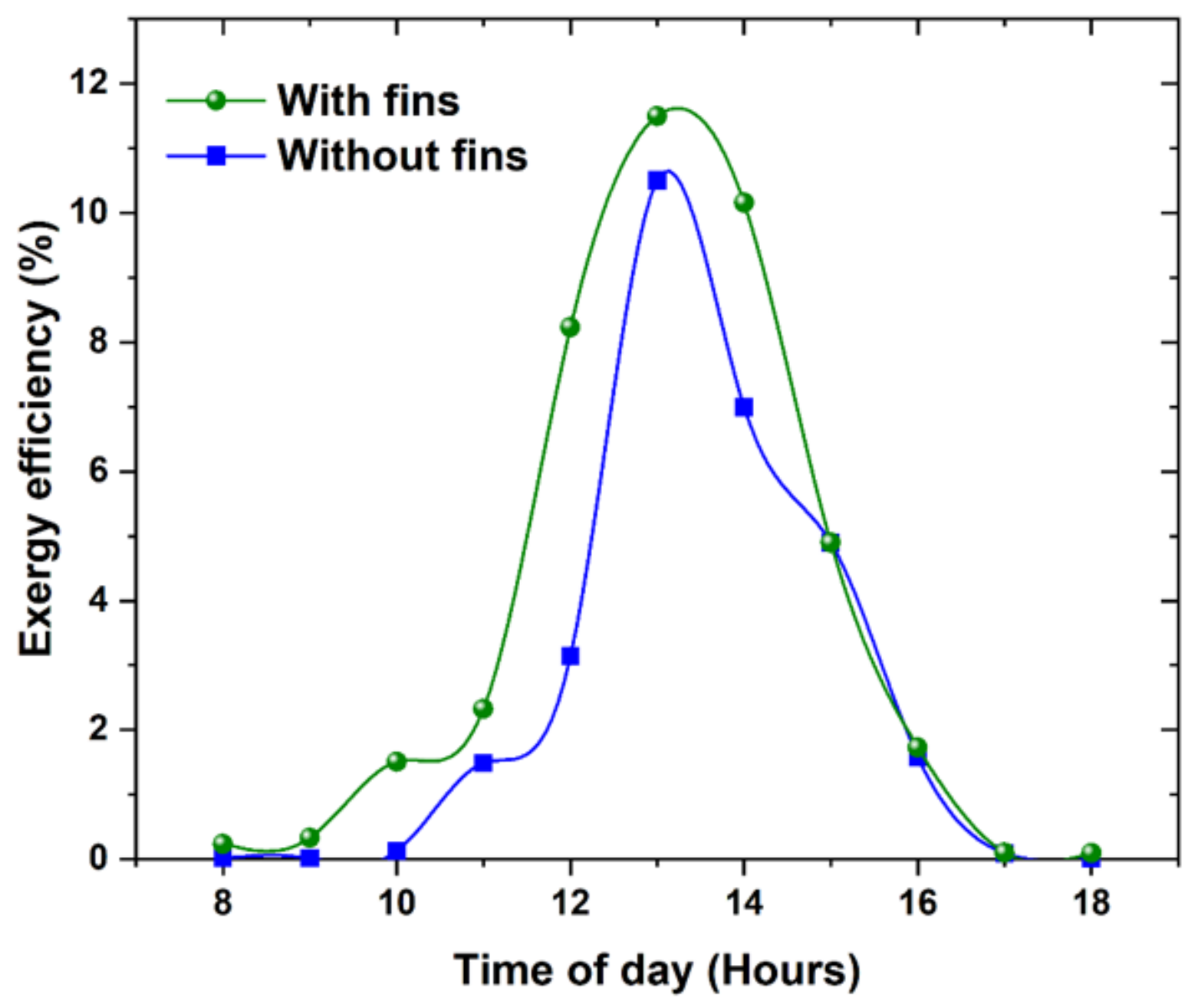

Figure 9

Instantaneous variations on exergy efficiency from TSS using flat and finned absorber 